\title{
A dinastia corporatista
}

\author{
GLAUCO ARBIX
}

RESUMO:Este ensaio examina a trajetória das formas mais recentes da teoria corporatista, em especial de suas versões democráticas - denominadas neocorporatista. Experiências positivas no terreno político, econômico e social, em particular as desenvolvidas em países europeus, ajudaram o corporatismo a distanciar-se do forte estigma moldado pelo fascismo e a recuperar seu espaço nos estudos das ciências sociais. No Brasil, a conformação da câmara do setor automotivo no início dos anos 90 revelou a emergência de mecanismos neocorporatistas na indústria. Circunscritos setorialmente e em um nível intermediário. Essa experiência que demonstrou eficácia econômica e política, é aqui analisada em sua dimensão mesocorporatista.

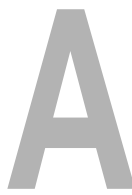

experiência das câmaras setoriais, em especial a do setor automotivo, em que pese sua fragilidade, deixou sua marca nas relações entre $o$ Estado, o Capital e o Trabalho no Brasil.

Através de um difícil movimento de concertação, os acordos selados na câmara (1992 e 1993) contribuíram para a redução da taxa de conflitos entre os sindicatos - em especial os vinculados à CUT - e as empresas do setor; protegeram os salários e o emprego, resultando em ganhos reais para os trabalhadores; impulsionaram decisivamente a recuperação da indústria, com impacto positivo sobre o conjunto da economia e sem lesar os cofres públicos, como chegou a ser prenunciado por apressados analistas.

A câmara do setor automobilístico nasceu como um escudo de resistência diante recessão e da abertura econômica efetivada pelo governo Fernando Collor. Anovidade, porém, foi que o seu desenvolvimento não esteve voltado para os velhos expedientes protecionistas, mas para uma real sintonia
UNITERMIOS: neocorporatismo, mesocorporatismo, câmara setorial, concertação, políticas públicas, organização de interesses.
Professor do Departamento de Ciência Política do IFCH-UNICAMP 
com os processos de globalização e modernização industrial. Com a vantagem de ter estabelecido um terreno de maior controle sobre seus efeitos perversos.

No entanto, desde o final do governo Itamar Franco e a ascensão de Fernando Henrique Cardoso, a câmara automotiva - assim como as demais câmaras - parece estar sendo drenada em suas atribuições, de modo a evitar que a negociação tripartite venha a ocupar qualquer lugar significativo nos dispositivos governamentais.

Luiz Adelar Scheuer, ex-presidente da ANFAVEA, chegou a declarar que a "câmara automotiva está praticamente morta" . E Vicente Paulo da Silva, presidente da CUT, interrogou-se sobre as razões da "burrice" que parecia ter tomado conta dos homens públicos e empresários deste país, "que estavam deixando morrer um processo democrático e eficaz de participação"2.

Katzenstein, dez anos antes, havia passado por dúvida semelhante, quando da ocupação do território americano pelos automóveis japoneses. "Será que o Estado é inteligente ou estúpido?" (Katzenstein, 1985, p. 19) perguntou então o pesquisador. E sem formular uma resposta precisa apenas indicou que o debate poderia mostrar-se inócuo se estivesse baseado em uma dicotomia simplificadora.

No Brasil, a questão de fundo é que desde o esgotamento do nacionaldesenvolvimentismo o Estado brasileiro tem demonstrado enormes dificuldades para reencontrar os trilhos do seu crescimento.

Nessa busca, a democratização da sociedade e a crise do sistema corporativista produziram uma multiplicidade de novas formas de organização de interesses e de relacionamento entre Estado e sociedade. Dentre estas, as câmaras setoriais se destacaram, mostrando-se politicamente inclusivas e subvertendo as relações tradicionais de elaboração e implementação de políticas industriais, apesar da acusação recorrente de que não passariam de resíduos do passado que os novos ventos encarregar-se-ão de varrer.

A discussão de peso, no entanto, está longe de ser nova.

Vários foram os autores que anunciaram a decadência irremediável do corporatismo em todo o mundo diante do avanço do liberalismo. Em nosso trabalho não fizemos coro com eles.

Apesar das pressões do novo ambiente econômico internacional, que se desenvolveu a partir do deslocamento das políticas keynesianas, é ingenuidade acreditar que os arranjos de concertação não têm mais espaço para vicejar, a não ser como entulho protecionista.

A reestruturação econômica e industrial que está em curso não é dotada

Depoimento de Luiz Adelar Scheuer, então presidente da Associação Nacional dos Fabricantes de Veículos Automotores (1994).

2 Depoimento de Vicente Paulo da Silva (1994). de características homogêneas e uniformes. Países, regiões, comunidades, setores
e mesmo empresas sempre tenderão a buscar uma configuração especial para aumentar seu poder de controle sobre as oscilações do mercado.

Se é verdade que do ponto de vista político as ações gerais de classe tendem a perder força em função da queda generalizada da ação sindical em todo o mundo, também é certo que está em curso uma segmentação cada vez maior do movimento sindical, diferenciando os setores mais organizados dos 
não organizados.

Para o capital, que teve aumentada a sua mobilidade, a efetivação de compromissos mais estáveis, capazes de diminuir as incertezas, pode vir a constituir-se em vantagem competitiva para regiões, países, setores ou ramos produtivos. Para os sindicatos, especialmente os que representam parcelas mais organizadas - que, tradicionalmente, dirigem as centrais - abre-se a oportunidade de selar acordos parciais compensadores, com ganhos reais para todas as partes envolvidas.

Isso significa que, contrariamente às expectativas, uma política geral de desregulação da economia, pode estimular seletivamente a emergência de formas especializadas de corporatismo. Os níveis intermediários da produção industrial capitalista são marcados por uma complexa diversidade de relações que dificilmente um só modelo de organização da economia poderia abarcá-los.

$\mathrm{Na}$ realidade, o desenvolvimento de políticas industriais em praticamente todo o mundo está exigindo o Estado, e não dispensando sua intervenção ${ }^{3}$.

A simplificação econômica, normalmente, vincula, de um lado, o livre mercado à política monetarista e ao neoliberalismo e, de outro, o corporatismo a uma política fiscal capaz de sustentar o crescimento e o pleno emprego. Os esquemas, freqüentemente, além de não elucidarem, acabam desabando sobre a cabeça de suas vítimas. Basta ver a perplexidade manifestada depois que o governo Fernando Henrique Cardoso aumentou as alíquotas de importação, utilizando-se de expedientes mais adequados a políticas protecionistas, entendidas hoje como extemporâneas.

Na era Collor, o principal móvel para o surgimento da câmara havia sido a recessão. Nos dias de hoje, a política de competitividade e a desnacionalização da economia parecem marcar a intervenção do Estado, ainda que seja difícil entregar-se totalmente ao mercado como meio de retomar o desenvolvimento econômico. Isso porque são muitos os laços que unem os destinos da indústria aos do Estado no Brasil. O que significa que as decisões unilaterais freqüentemente são penalizadas. Além disso, em quase todos os setores industriais que sustentam a economia nacional as entidades sindicais dos trabalhadores sobrevivem com força, exibindo uma alta concentração de associados.

Essa malha de ligações e de poderes informa o posicionamento de toda uma franja de empresas que prefere evitar os conflitos, abrindo espaço para o que Streeck (1985) denominou de cooperação produtiva que, patrocinada pelo Estado, emerge com o nome de coordenação intermediária, ou mesocorporatismo.

Evidentemente, o corporatismo não representa a única maneira de as empresas relacionarem-se com o Estado. Por isso mesmo recusamos qualquer fatalismo na discussão sobre a via a ser seguida. Apenas avaliamos que as câmaras, se revitalizadas, não serão constituídas como uma idéia fora de época e de lugar.

${ }^{3}$ Ver a esse respeito o estudo sobre a Inglaterra de Kevin Bonnett (1985). 
Foi com essa preocupação que procuramos estabelecer a discussão sobre a natureza das câmaras setoriais e a sua relação com os arranjos neocorporatistas, mais especificamente mesocorporatistas, que estão emergindo e se consolidando em várias regiões do mundo.

\section{Luzes e sombras}

Fortemente tentada à construção de modelos explicativos, não foram raros os momentos em que a sociologia pensou ter encontrado um método que pudesse ser colocado em qualquer mão, capaz de se tornar, assim, uma espécie de ferramenta universal.

Starobinski, que nunca se pretendeu sociólogo, mas sempre buscou com suas antenas a sintonia fina com os objetos culturais, não deixou de nos alertar sobre o que ele denominava "terrorismo metodológico". Ou seja, a construção de "instrumentos rudimentares", que, na maior parte das vezes, produz ilusões com aparência científica, "aos quais nada, homens ou livros, culturas ou línguas, tenha o direito de recusar seu segredo" (Starobinski, 1970, p. 12).

Ao estudarmos os processos de transição, em que os contornos do velho e do novo não se manifestam claramente delineados, as palavras de Starobinski ajudaram-nos a entrever caminhos entre o ceticismo e a prepotência científica. Os períodos de mudança, com seus diferentes matizes, sentidos vários, amálgamas de ambigüidade e contradições, engendram uma rede de complexidades, que o simples jogo das luzes contra as sombras nem sempre é capaz de iluminar.

Quando nos debruçamos sobre as teorias mais recentes do corporativismo - ou corporatismo, como discutiremos mais à frente-, notamos a ausência de unanimidade entre seus principais porta-vozes e variações nos conceitos-chave, que, muitas vezes, dificultam a exata compreensão de seus pressupostos essenciais.

Mais ainda, e principalmente, percebemos a ausência de uma arquitetura teórica completa e totalizadora. Ou seja, o instrumental desenvolvido nos últimos vinte anos pelos pesquisadores do corporatismo ajudaram-nos a compreender partes de um sistema político e econômico. Isso significa que em nosso trabalho, corporatismo foi utilizado apenas como um middle order concept $t^{4}$, capaz de nos auxiliar na captura de alguns fenômenos recentes no interior da realidade brasileira.

Na verdade, sentimo-nos como que atraídos por essa limitação. A suposta fragilidade dessa teoria em construção viria a mostrar sua força exatamente ali onde outros sistemas têm falhado em sua capacidade explicativa.

As noções que utilizamos realçaram a emergência de novos arranjos

A expressão encontrase em Alan Cawson (1986). 
se manifestam com nitidez.

Mais do que um processo estático, em que grupos de interesse apresentam suas demandas às autoridades estatais, as estruturas quase-públicas por nós estudadas envolvem relações de intercâmbio e interdependência entre seus membros e o Estado.

Nos últimos vinte anos, uma nova literatura começou a produzir explicações exatamente sobre o significado político dessas estruturas semipúblicas, que foram chamadas de neocorporatistas, por se conformarem, desta vez, em sociedades capitalistas modernas e democráticas.

Buscando uma primeira aproximação, e ainda em um nível geral, quando falamos em corporatismo, referimo-nos basicamente às relações de intercâmbio entre grupos de interesse e o Estado, que se dão através de mecanismos institucionalizados 5 .

Esses mecanismos, apesar de possuírem pontos de contato com formas mais antigas, são fenômenos recentes. O seu surgimento está vinculado às alterações na estrutura e na forma de intervenção dos Estados modernos, que vêm perdendo a capacidade de controle sobre a vida econômica e social, em particular a partir do esgotamento do chamado ciclo virtuoso do pós-guerra.

Williamson afirmou que "o corporatismo tanto pode ser entendido como uma nova maneira de olhar para as coisas, como um novo conjunto de coisas para serem olhadas" (1989, p. 7), sugerindo uma (re)leitura global de novos e velhos fenômenos.

Neste trabalho, porém, tomamos o seu comentário apenas como um convite à reflexão sobre a câmara do setor automotivo.

\section{Uma Palavra-valise ${ }^{6}$}

Até o início dos anos 70, o termo corporativismo aparecia nos estudos acadêmicos associado a regimes autoritários de todo tipo, sendo que, em alguns países democráticos, era utilizado para nomear o envolvimento dos grupos de interesse com a burocracia e as autoridades públicas.

Em seu uso corrente, o termo corporativismo é utilizado para designar clientelismo, ação de lobbies, agrupamentos egoístas, parasitismo e sistema de colaboração entre classes. Ou seja, corporativismo sugere imediatamente as mais diferenciadas ações em busca de benefícios particularistas junto ao setor público em detrimento do "bem comum". Nestes casos, o Estado é visto apenas como um elemento passivo, um receptor de demandas dos interesses privados, os únicos realmente existentes.

Em português, o termo corporativismo é encontrado nos dicionários apenas como uma "doutrina que prega a reunião das classes produtoras em corporações, sob a fiscalização do Estado"7 . Diferentemente, por exemplo, das línguas inglesa, alemã e espanhola, que, por comportarem tanto "corporativismo" como "corporatismo", permitem uma utilização mais adequada ao que se pretende descrever: se uma doutrina ou um membro de um
${ }^{5}$ As estruturas a que nos referimos não se confundem com o modelo sindical corporativista, analisado em suas características básicas por: Rodrigues (1990); Boito (1991).

${ }^{6}$ A expressão foi emprestada do poeta Augusto de Campos.

7 Novo dicionário Aurélio da língua portuguesa; O grande dicionário etimológico-prosódico da língua portuguêsa (1964), registra o termo como: "doutrina política, fascismo, sindicalismo, etc". 
8 Por exemplo, na língua inglesa, o adjetivo corporative significa: Governed or organized in corporations, esp. of employers and employed, e tem como substantivo a palavra corporativism; encontramos também o adjetivo corporate, que significa: forming a corporation (corporate body), e tem corporatism como substantivo, segundo o The Oxford dictionary of current english (1990). De acordo com o Latin Dictionary (1987), no latim clássico encontramos o adjetivo corporativus, significando "de ou pertencente à formação de um corpo"; e o substantivo corporatus, "membro de uma corporação", que podem estar na origem da diferenciação ocorrida no inglês, alemão e espanhol, mas que não ocorreu no português. corpo, se um sistema de acomodação entre classes sociais ou manifestações de apetites individuais ${ }^{8}$.

Mesmo assim, utilizações distintas acabaram por sedimentar uma profusão de imagens associadas à palavra e à idéia de corporativismo, das quais selecionamos as seguintes:

1) A primeira seria a das corporações da Idade Média e do Ancien Régime, verdadeiras ilhas de proteção social, ainda que acessíveis somente a uma minoria da sociedade;

2) Uma segunda imagem, seria a das práticas corporativas vinculadas ao fascismo italiano, aos regimes totalitários de Franco, Salazar, Vichy, ao nazismo, que, apesar das diferenças, procuraram erguer sistemas de enquadramento da sociedade, centrados no Estado e no partido. $\mathrm{O}$ corporativismo surgia como um sistema de contenção de conflitos, ainda que pudéssemos fazer inúmeras distinções sobre o grau de coerção e autoritarismo que foram incorporados às suas manifestações mais concretas.

Primo de Rivera, na Espanha, nunca deixou de manter pontos de contato com o Partido Socialista e a Confederação Sindical de Largo Caballero. Apesar das pretensões à autonomia manifestadas em vários momentos pelos novos sindicatos fascistas, entre 1922 e 1929, Mussolini manteve-os sob seu controle, deixando claro que a coordenação corporativista das forças sociais era a marca central do fascismo. Na Alemanha, a legislação de fevereiro de 1934 instituiu a Frente do Trabalho, única responsável pela representação dos trabalhadores no interior do regime nazista (cf. Maier, 1984, p. 45).

Williamson (1985) observou que, sob muitos aspectos, o edifício corporativista do fascismo ou do salazarismo, por exemplo, era uma espécie de ficção, destinada apenas a demonstrar que os conflitos da sociedade préfascista poderiam efetivamente terminar. Ou seja, assim que a autonomia do movimento dos trabalhadores fosse liquidada, as instituições corporativas perderiam muito de sua função.

Se pudéssemos aprender alguma lição desse aparente paradoxo, diríamos que a proposta corporativista perde força quando as partes envolvidas não conseguem mais reconhecer os conflitos que as separavam.

3) A terceira, teria origem na tradição operária e sindical européia. Nesta, a ação corporativista se contrapunha à ação de classe, ensejando uma tensão entre o particular e o universal, entre o egoísmo de uma categoria (ou do pequeno grupo) versus a solidariedade de classe. Nas origens da industrialização capitalista - cujo avanço quebrou as aldeias, comunidades e as guildas - propostas como as "empresas modelo" de Robert Owen, a "companhia operária" de Proudhon, os "falanstérios" de Fourier ou os "ateliês sociais" de Louis Blanc provocaram vivas polêmicas.

Para os grupos e sindicatos que realçavam a ação político-ideológica como essencial para a delimitação das classes sociais, seria possível a superação da poussière d'individus inorganisés de que falava Durkheim através do aprendizado classista: os núcleos operários que tentavam se defender contra a 
fragmentação capitalista deveriam abraçar um visão política globalizadora.

Já no início do século XX, porém, a nova sociedade industrial começava a aparecer menos atomizada e individualizada. A presença de Estados nacionais fortes, de grandes empresas, da emergência dos grandes bancos e da adoção de estratégias protecionistas em vários países, estimularam Hilferding a falar de um capitalismo organizado.

A emergência dos sindicatos de massa e de partidos ligados aos trabalhadores possibilitaria a superação política dos conflitos entre as corporações e as ações classistas: o universal seria capaz de se encarnar no particular, desde que mediatizado pelo partido, depositário da consciência histórica da classe.

Apesar dessa possibilidade, a tradição sindical militante legou-nos uma imagem do corporativismo como atraso, falsa consciência ou regressão para o movimento operário - ou para a classe trabalhadora, para a nação ou mesmo para a humanidade, dependendo do nível em que viesse a se manifestar.

Não deixa de ser interessante notar que o corporativismo registraria seus melhores resultados exatamente no meio sindical, seja pela fraqueza dos partidos, pela força das corporações ou porque a relação entre trabalhadores, sindicatos e partidos estaria desobedecendo a lógica (imanente) de formação da consciência de classe.

4) A Igreja católica assentou as bases de uma quarta imagem do corporativismo, ao criticar o individualismo capitalista e condenar os conflitos de classe. O tema da comunidade de interesses entre empresários e trabalhadores ocupou lugar especial na encíclica divulgada pelo Papa Leão XIII, em 1891. Seus princípios básicos afirmavam a "necessidade de união entre as duas classes (...) cujo destino natural era a união harmônica e a convivência em perfeito equilíbrio"(Encyclique Rerum Novarum, 1932, p. 27,\#15).

O mesmo tema seria desdobrado em meio aos acontecimentos que abalaram a Europa a partir dos anos 20: a carta do Papa Pio XI, de 1931, declarava que os conflitos só seriam acalmados

"Com a substituição das classes oponentes por órgãos bem constituídos, 'ordens'e 'profissões' que agrupam os homens de acordo com os diferentes ramos de atividade social aos quais estão ligados e não segundo a posição que ocupam no mercado de trabalho (...) Os membros de uma mesma profissão tendem, por natureza, a criar grupos corporativos, ainda que muitos os considerem órgãos essenciais ou, pelo menos, naturais na sociedade" (Encycleque Quadragesimo Anno, 1937, p. 221 \# 90 e 94).

Essas caracterizações, endereçadas à sociedade em geral, e aos trabalhadores em particular, estavam na base das propostas de "paz social" disseminadas pela Igreja católica, e que localizavam nas estruturas corporativas um canal de convergência de interesses que a crítica socialista via como opostos. 
5) A quinta imagem seria uma versão vulgarizada do mecanismo corporativista. Este seria caracterizado fundamentalmente pelo desejo de fazer prevalecer, de modo injustificável, os interesses de um grupo ou categoria sobre os interesses gerais. Seria uma espécie de culto dissimulado à diferença e ao privilégio, diante do medo da concorrência aberta e da livre iniciativa.

Segundo essa visão, quase todos os membros e grupos das sociedades contemporâneas - e não só a classe operária - seriam corporativos, do homem comum aos grandes conglomerados econômicos.

$\mathrm{Na}$ França republicana, muitos movimentos, inclusive sindicais, seriam influenciados pelas teses de Durkheim sobre a divisão do trabalho, desfazendo a imagem que somente católicos e monarquistas defendiam idéias corporativas. Incorporando no seu pensamento a emergência das associações profissionais, Durkheim considerava necessário para o equilíbrio político e moral da sociedade que se preenchesse o vazio deixado pelas corporações.

Para o pensador francês, a corporação profissional deveria tornarse novamente uma instituição pública, na medida em que:

"Um Estado hipertrofiado, esforçando-se para abarcar e coesionar uma sociedade composta por uma poeira infinita de indivíduos desorganizados, constitui uma aberração sociológica (...) Uma Nação só pode se manter com uma série de grupos secundários, suficientemente próximos dos indivíduos, posicionados entre estes e o Estado, de modo a atrai-los para a esfera da ação e conduzi-los para o curso geral da vida social" (Durkheim, 1978, p. XXXIII).

No entanto, sempre é bom lembrar, os "egoísmos" e os "interesses" podem variar em qualidade e quantidade, e não há forma de aferir sua exata dimensão. Isso significa que a vida em sociedade estaria dificultada se, diante de cada caso, fossem cotejados os desejos, a partir da afirmação da humanidade acima da nação, desta sobre os estados, destes acima das cidades, das classes, das profissões, dos grupos e dos indivíduos e assim por diante.

Provavelmente esse automatismo tenderia a camuflar - ou a afirmar com base na autoridade - quem poderia definir os interesses "inferiores" e os "superiores" que supostamente estariam sendo corroídos.

Essa imagem, que aproxima concepções liberais de um marxismo vulgar, não consegue explicar porque em muitas manifestações de corporativismo podem ser encontrados ideais de solidariedade e não somente "egoísmos de fração", como dizia Gramsci.

6) A sexta imagem estaria ligada a um novo corporativismo, que vem se manifestando exatamente onde a social-democracia enraizou-se fortemente. Nestes países, os partidos social-democratas sustentaram regimes estáveis, baseados em macro-negociações entre o Estado, os sindicatos e o patronato, envolvendo grandes temas sociais e econômicos, como o pleno 
emprego, a redução das desigualdades, a implementação de políticas sociais distributivistas, a democracia e outros.

No entanto, a crise da economia mundial e o esgotamento da política keynesiana depois do ciclo virtuoso do pós $-2^{\text {a }}$ guerra, vem minando a capacidade de financiamento dos Estados de Bem-Estar e provocando distúrbios nas políticas da social-democracia. Nessas condições, Rosanvallon observou que no interior de sistemas sustentados em macro pactos sociais, estaria se expressando um corporativismo de tipo novo, que ele chamou de "socialcorporativismo" (Rosanvallon, 1984, p. 104). Segundo este autor, as macro negociações teriam cedido lugar a políticas fragmentadas, sem perspectiva de longo prazo e que procuram apenas acalmar tensões sociais e evitar rupturas

A característica básica desse "social-corporativismo" seria a substituição dos grandes atores por outros não tão grandes, que Barel comparou a uma espécie de "metonímia social"(Barel, 1988, p. 27). Seu questionamento tem sido incisivo: quais seriam os atores que hoje, efetivamente, fazem parte das negociações? O Estado ou alguns ministérios? Os ministros ou técnicos de planejamento? As centrais sindicais ou alguns sindicatos? Estes ou algumas executivas? Alguns secretários gerais ou seus assessores técnicos?

Os sinais estariam indicando um processo de regressão em curso no modelo social-democrata, em particular nos países do norte da Europa.

Nesta imagem, o social-corporativismo seria o "modo de vida de uma parte em relação ao conjunto ao qual pertence"; mas, segundo Barel, estaria se conformando também como "uma nova maneira do próprio conjunto se comportar, uma nova maneira de pensar e de fazer política" (Barel, 1988, p. 26).

Diante da multiplicidade de sentidos que a palavra "corporativismo" carrega, dos quais descrevemos seis, Jobert e Muller apresentaram-na como uma noção "polisêmica”(1987, p. 152), cuja utilização indiscriminada para designar fenômenos e processos que se diferenciaram através dos tempos teria dado origem a esse entrelaçamento de sentidos.

Em nosso trabalho, as expressões do corporatismo que analisamos surgiram no interior de sistemas políticos democráticos, baseados em instituições parlamentares, divisão de poderes e liberdades civis.

$\mathrm{O}$ velho corporativismo pressupunha a tentativa do Estado de representar, absorver e identificar-se com a sociedade. A emergência do novo corporatismo estaria se dando nas mais diferentes esferas da vida econômica e social, gerando uma situação paradoxal em que o "mercado capitalista está assentado em um consenso normativo de pressupostos que não são de mercado"(Maier, 1984, p. 40), uma vez que não pode prescindir dos mecanismos de regulação.

Como alertou Schmitter, o Estado moderno, para melhor cumprir suas funções, e sob certas circunstâncias, tende a dividir seu poder de definição das políticas públicas com associações de interesse - que detêm informações e conhecimento-, através de estruturas institucionalizadas.

Essa distinção básica entre o (velho) corporativismo e o 
(neo)corporatismo abriu portas pelas quais entraram novas gerações de pesquisadores com uma seqüência de pesquisas inéditas. Foi a partir do trabalho seminal de Philippe Schmitter, Still the century of corporatism? (1974), que Williamson pôde afirmar que uma "dinastia corporatista havia efetivamente começado em 1974” (Williamson, 1989, p. 10).

Para acentuar a contemporaneidade desse conceito, e procurando aliviá-lo de velhos fardos, utilizaremos ao longo do nosso trabalho as designações corporatismo e corporatista, acompanhados das expressões novo ou neo.

Permitimo-nos esses neologismos por empréstimo do inglês, em função da conotação ideológica e depreciativa dos termos corporativismo e corporativista em português ${ }^{9}$.

\section{Pluralismo versus corporatismo}

9 Essa formulação foinos gentilmente elaborada pelo Prof. Dr. Francisco da Silva Borba, do Departamento de Linguística da Faculdade de Ciências e Letras da UNESP, do campus de Araraquara. Outros pesquisadores do corporatismo, como o Prof. Dr. Walter Belik, do Instituto de Economia da UNICAMP e Fernando Soto Baquero, doutor pela UNICAMP, utilizamse do mesmo neologismo. A tradução da obra de Mihail Manoilesco, O Século do Corporativismo, realizada por Azevedo Amaral, em 1938, utiliza indistintamente os termos corporativismo e corporatismo.

${ }^{10}$ Mais de uma vez Hobbes alertou-nos para a impertinência dos organismos intermediários entre o Estado e o indivíduo, como os partidos, as associações e as corporações que agiam, segundo o pensador, "como vermes nas entranhas de um homem natural" (Hobbes, 1952, p. 152).
O ensaio desbravador de Schmitter (1974) foi publicado originalmente em uma coletânea de artigos sobre a América Latina e procurava afirmar o corporatismo mais como uma estrutura institucional determinada no tempo e no espaço do que uma forma de elaboração de políticas.

Sua pesquisa sobre o Brasil e vários outros Estados autoritários revelou que o Leviatã moderno, mesmo enfraquecido, não dispensava o relacionamento com os "vermes" sociais contra os quais nos previnira Hobbes ${ }^{10}$.

A partir de uma releitura crítica, o pesquisador repensou as idéiaschave do romeno Mihail Manoilesco, para quem a concepção corporatista e o conceito do Estado corporativo seriam:

"Necessidades lógicas imperiosas no século XX, tal qual oforam a idéia individualista e o Estado liberal no século XIX. O conceito corporativista representa hoje o futuro, do mesmo modo que o princípio liberal era o futuro em 1789”(Manoilesco, 1938, p. XIV).

O esforço de Schmitter para dar ao termo corporatismo um tratamento rigoroso somente frutificaria quando o conceito passou a ser definido em função de sua praxis.

Por se tratar de uma modalidade moderna de representação, o neocorporatismo passou a designar os mecanismos emergentes na sociedade capitalista, relacionados às necessidades de sua reprodução e acumulação, e que se diferenciavam de acordo com sua origem.

Quando esses mecanismos nasciam de uma imposição do Estado em processos típicos de regimes autoritários, como em Portugal, Espanha, Brasil, Chile, Peru, México e Grécia - davam origem a um corporatismo estatal; quando surgiam voluntariamente da sociedade, respondendo ao livre jogo de pressões, configuravam um corporatismo societal - que se manifestava tipicamente na Suécia, Suíça, Holanda, Noruega e Dinamarca, mas que também estava se conformando na Grã-Bretanha, na Alemanha, França, Canadá e nos Estados Unidos. 
Não se tratava de um problema semântico: a distinção entre esses subtipos de neocorporatismo devia-se à tentativa de captar as mais diferentes relações de poder e de influência que se manifestavam.

O corporatismo estatal baseava sua ação na autoridade do Estado, seja para submeter os grupos de interesse da sociedade, seja para criá-los de acordo com sua conveniência. Seu modo de funcionamento assentava-se na busca da identificação do Estado com a sociedade, levando o privado a expressar-se através do público.

O corporatismo societal tinha origem em processo diverso, no qual a autonomia dos grupos de interesse da sociedade se afirmava no relacionamento com o Estado. Ainda que este mantivesse forte sua presençapois sem o Estado não há mecanismo corporatista - as relações entre os membros do arranjo realçam o caráter de intercâmbio e de troca recíproca.

A partir de especificações empíricas, que diziam respeito a práticas recentes de representação de interesses, Schmitter foi conduzido à primeira tentativa de conceitualização:

"O corporatismo pode ser definido como um sistema de representação de interesses no qual suas unidades constitutivas estão organizadas em um número limitado de categorias, compulsórias, não-competitivas, hierarquicamente ordenadas e funcionalmente diferenciadas, reconhecidas ou autorizadas (se não criadas) pelo Estado, às quais se outorga o monopólio da representação no interior de suas respectivas categorias em troca da observância de certos controles na seleção de seus líderes e na articulação de suas demandas e apoios"(Schmitter, 1974, p. 93-94) ${ }^{11}$.

A idéia central que norteava Schmitter indicava que um sistema era neocorporatista porque estava institucionalmente estruturado de modo a restringir a competição entre seus membros.

Um importante passo era dado na via de diferenciação com a corrente liberal então dominante, conhecida por pluralista, que caracterizava os sistemas de organização de interesses pela livre concorrência entre seus membros e pela sua independência em relação ao Estado.

Para Schmitter, o pluralismo era visto como um sistema em que o livre mercado possibilitava a dinâmica dos grupos de pressão; enquanto que o corporatismo era um sistema que, para funcionar, exigia o consentimento do Estado.

Essas caracterizações gerais foram construídas a partir de arranjos corporatistas observados em várias partes do mundo ${ }^{12}$, mas Schmitter entendia essas definições como descrições de tipos-ideais, como construções lógicoanalíticas compostas a partir de vários elementos teóricos e hipotéticos que não pretendiam adequar-se a nenhuma realidade empírica em particular.

Para sintetizar, a vertente aberta por Schmitter abordava o corporatismo como um "sistema de representação de interesses e/ou atitudes,

\footnotetext{
${ }^{11}$ Grifos nossos.

${ }^{12}$ Foram nomeados pelo autor: a Suécia, Suíça, Noruega, Áustria, Espanha, Holanda, Dinamarca, Portugal, Grécia, Brasil, México, Chile e Peru (Schmitter, 1974, p. 99).
} 
um modo particular ou um tipo ideal de arranjo institucional para ligar os interesses organizados da sociedade civil com as estruturas de decisão do Estado"(Schmitter, 1974, p. 86).

\section{A concertação}

A partir da Alemanha, Gerhard Lehmbruch, traria à tona na mesma época, porém sem contato direto com Schmitter, novos elementos para a discussão. Em seus estudos tratou do "corporatismo liberal", que, segundo ele, pressupunha a participação dos grandes interesses na elaboração de políticas públicas. $\mathrm{O}$ centro de suas preocupações voltava-se para o processo de cooperação entre os grupos envolvidos no arranjo. A cooperação, mais do que o conflito, aparecia como um reconhecimento das lideranças da "interdependência dos interesses entre grupos sociais conflitantes na economia capitalista" (Lehmbruch, 1979, p. 55) ${ }^{13}$.

Ao se ater ao processo de negociação - mais do que na valorização das estruturas, até então enfatizadas por Schmitter - Lehmbruch destacou a relativa autonomia que as lideranças acabavam tendo em relação aos seus representados.

O corporatismo surgia, assim, como uma espécie de sistema de filtros, que integrava os mecanismos de manutenção da estabilidade social. Com essa abordagem, Lehmbruch destacava o processo de trocas internas, expandindo ainda mais o conceito de corporatismo.

Havia um claro ponto de contato entre as visões de Schmitter e Lehmbruch, na medida em que ambas realçavam a natureza fechada e centralizada dos grupos de interesse, embora as abordagens se diferenciassem quanto à análise do modo como se processavam suas demandas.

Os estudos de Lehmbruch permitiram a compreensão do corporatismo como um sistema e como um processo político. Através da primeira vertente procurava sintetizar as várias faces do corporatismo em um conceito pluridimensional, o que o levou à construção de um sistema classificatório internacional, a partir de pesquisas comparativas entre vários países. Com a segunda, realçava o neocorporatismo como um processo de intermediação e de implementação de políticas ${ }^{14}$.

${ }^{13}$ De acordo com Peter Williamson, este artigo foi originalmente publicado como um paper, em 1974, para um seminário da International Political Science Association.

${ }^{14}$ Pouco tempo depois, Alan Cawson retomaria e ampliaria a trilha aberta por Lehmbruch (cf. Cawson, 1985a).
Lehmbruch deu realce ao que chamou de concertação corporatista, que envolvia:

1) "não apenas um único interesse com acesso privilegiado ao governo mas também uma pluralidade de organizações representando, geralmente, interesses antagônicos";

2) "essas organizações administram seus conflitos e coordenam suas ações com o governo observando as exigências sistêmicas da economia nacional" (Lehmbruch, 1984, p. 62).

Para Lehmbruch, mais importante do que "representação de interesses" seria a concertação corporatista, que só ocorria entre o Estado e 
grupos de interesse com alto grau de representatividade em seus respectivos setores. De fato, o pesquisador procurava mostrar que os comportamentos meramente protecionistas estavam cedendo lugar a um processo de interação com a sociedade, uma vez que "os parâmetros macroeconômicos também eram influenciados pelos interesses das grandes organizações" (Lehmbruch, 1984, p. 64).

Lehmbruch comparou políticas e estruturas de vários países identificando níveis de concertação que manteriam relação com o grau de desenvolvimento de acordos de longo-prazo estabelecidos entre as partes.

Em um primeiro nível, Lehmbruch localizou as relações que buscavam apenas um planejamento indicativo e uma troca de informações sobre salários, lucro, investimentos e emprego. A concertação, nesses casos, prescindiria de compensações e visava a criação de consenso genérico sobre a intervenção na economia.

Em um grau mais avançado de concertação, Lehmbruch detectou as transações que envolviam formalmente trocas e compensações entre as partes.

O terceiro nível incluiu o intercâmbio que só ganharia estabilidade a partir do estabelecimento de relações de longo-prazo entre o Estado e os diversos segmentos sociais. A base desses acordos residia na disposição das partes envolvidas de não perseguirem benefícios equivalentes em cada troca efetivada. Ou seja, as compensações com paridade dar-se-iam ao longo de todo um período, em função do planejamento acordado.

Lehmbruch trabalhou os casos da Áustria e da Suécia como exemplos desse tipo de concertação. A partir desses casos procurou mostrar como as compensações parciais, eram, muitas vezes, substituídas por uma maior interferência na política econômica nacional, resultando em maiores benefícios para as partes, em particular para os trabalhadores e seus sindicatos.

A partir de um estudo mais amplo dos países europeus Lehmbruch elaborou um quadro em que procurou caracterizar as concertações duradouras e as instituições corporatistas que as sustentaram.

Nesse sentido, uma participação intensa de trabalhadores e de empregadores na formulação e implementação de políticas ensejou um sistema de "corporatismo forte". Quando a participação do Capital e do Trabalho foi limitada apenas a setores ou a algumas fases da formulação de políticas públicas, tomou forma um sistema de "corporatismo fraco". Um "corporatismo médio" configurou-se em países onde a negociação coletiva foi ampla, mas cujos resultados foram apenas temporários.

Para Lehmbruch, a ausência de concertação foi descrita como "pluralismo". A França e o Japão aparecem como países em que se dá uma "concertação sem o trabalho".

O quadro abaixo, que Lehmbruch construiu, indicou o seguinte: 
Escala crescente de corporatismo

Quadro 1 Fonte: Lembruch, (1984, p. 66).

\section{Escala crescente de corporatismo}

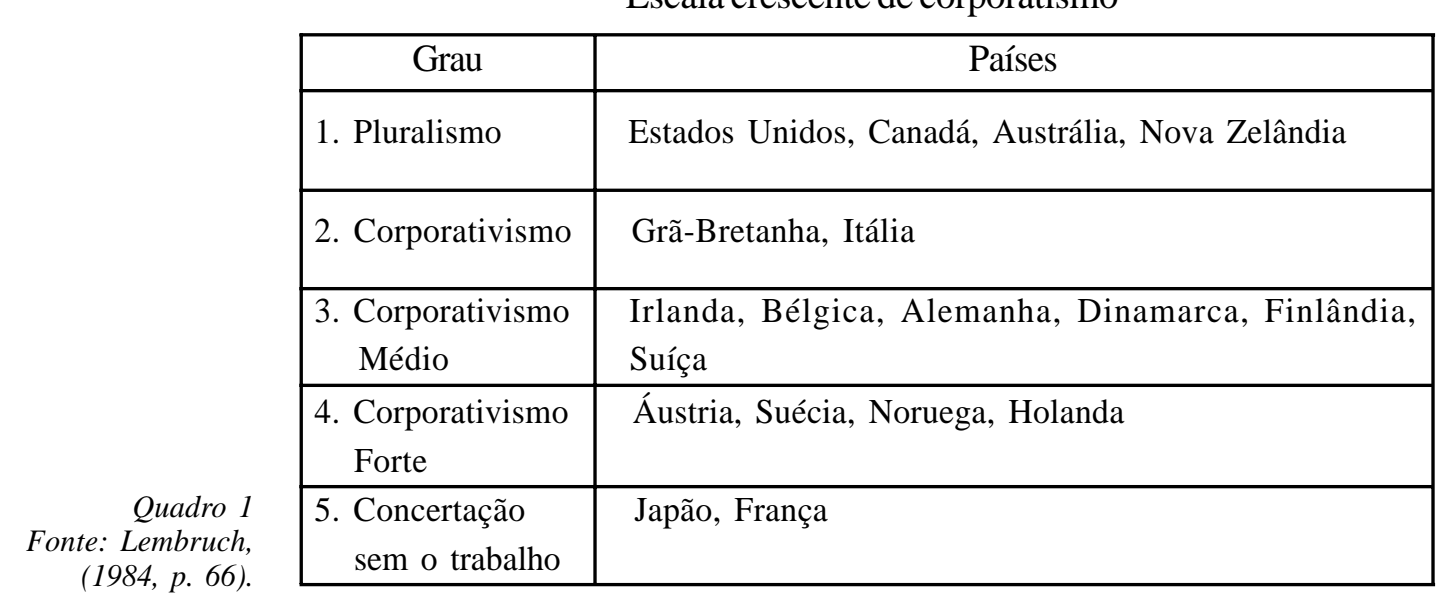

Para Lehmbruch, essa classificação não era fixa, uma vez que as relações e as instituições podiam movimentar-se no tempo e no espaço.

Se olhássemos as articulações na economia brasileira de hoje, procurando genericamente relações corporativistas, provavelmente seríamos tentados pela velha tradição a posicionar o Brasil entre os primeiros na escala Lehmbruch de corporativização. Trabalhando com uma definição mais precisa de corporatismo - como mecanismos de elaboração e implementação de políticas públicas, vinculados às transformações democráticas e à busca de maior eficácia na formulação de políticas industriais - talvez localizássemos o Brasil em algum lugar além do ponto 4 e mais próximo do ponto 5 da tabela acima.

Os critérios de Schmitter e Lehmbruch deram aos estudos sobre o corporatismo maior relevância e possibilitaram uma avaliação prática das relações entre as agências estatais e os grupos de interesse organizados. Constatou-se então, empiricamente, que a participação das grandes organizações - de empresários e de trabalhadores - através de estruturas organizacionais voltadas para a implementação de políticas concertadas, resultava em uma coordenação estratégica da economia mais eficaz.

Na mesma direção, só que a partir de estudos sobre a Grã-Bretanha, Alan Cawson rastreou o surgimento de arranjos corporatistas setoriais, vinculando-os à forma de intervenção do Estado.

Cawson propôs uma distinção entre os grupos segundo "seu significado para as atividades do Estado e de acordo com suas preocupações subjetivas" (Cawson, 1978, p. 178), e descreveu três níveis de organização de interesses e de organização do Estado: o macro, o meso e o micro.

No primeiro, a negociação seria necessariamente tripartite, e realizarse-ia entre o Estado e as mais importantes (peak) organizações do Trabalho e do Capital. Em seu nível meso, participariam as organizações preocupadas em defender interesses específicos de um setor ou de profissões. E no microcorporatismo, teríamos um relacionamento especial entre o Estado e uma grande 
empresa privada.

Esse modo de equacionar os arranjos de intermediação e de concertação de interesses, acreditamos, representou um ponto de inflexão na construção de uma teoria corporatista.

\section{0 nível meso}

Cawson reelaborou a definição conceitual de neocorporatismo, que passaria a ser concebido como a expressão de:

\begin{abstract}
"um processo sócio-econômico específico no qual as organizações representantes de interesses monopolíticos-funcionais, através de um intercâmbio político com as agências estatais, comprometem-se em alcançar resultados das políticas públicas; esse movimento leva essas organizações a desempenhar papéis que combinam representação de interesses $e$ implementação da política através de autocontrole (delegado)" (Cawson, 1985b, p. 8).
\end{abstract}

Ou seja, o corporatismo não seria visto apenas como um canal de expressão de grupos de interesse; e também não seria caracterizado somente pela forma de atuação do Estado, embora a intervenção estatal fosse vital para a sua configuração. Segundo Cawson, o toque diferenciador do corporatismo de outros arranjos seria exatamente a junção da representação e da intervenção no relacionamento entre grupos de interesse e o Estado.

Essa concepção indica que, para Cawson, a marca principal do neocorporatismo é a fusão de intermediação de interesses (representação e controle) e um modo específico de intervenção pública. Esta intervenção implica um processo de negociação de políticas, uma forma concertada, que envolve uma interação regular, paridade de representação e um processo de convergência mais do que de competição.

Se dissecarmos essa caracterização, vamos encontrar nos mecanismos neocorporatistas a presença de três lógicas:

1) a dos associados (relações entre as associações e seus próprios membros); 2) a da influência, que se manifesta no relacionamento entre as várias associações e o Estado; 3) e uma lógica da organização, que trabalha o próprio arranjo como uma arena de oportunidades e restrições (Cawson, 1985b, p. 12).

Essas indicações já nos permitiram observar na trajetória da câmara do setor automotivo (cf. Arbix, 1996), em especial nos seus dois primeiros anos de existência, que:

1) a câmara conformou-se como um espaço institucionalizado (as câmaras foram criadas por lei) de intermediação de interesses, do qual participam agências estatais e um número limitado de grupos sociais organizados, com o monopólio da representação concedido (parcialmente) pelo Estado ${ }^{15}$.
${ }^{15}$ Uma análise acurada do papel desempenhado pelo Estado no estabelecimento das estruturas sindicais (de empregados e de empregadores), na determinação do monopólio de representação e na organização compulsória dos segmentos produtores pode ser encontrada em Leôncio Martins Rodrigues (1990 e 1991). 
2) várias políticas públicas para o setor automotivo foram definidas em comum pelos seus integrantes. Agências estatais, juntamente com os sindicatos de trabalhadores e de empregadores, associações e representantes de empresas e de movimentos, formularam e implementaram, na maior parte das vezes, as decisões aprovadas;

3) as decisões da câmara foram tomadas, em sua maioria, de modo consensual;

4) a implementação das decisões acordadas deram-se através de mecanismos formais e informais, de modo a permitir a pressão e a vigilância de todos sobre todos, assim como a auto-fiscalização através dos seus grupos de trabalho;

5) finalmente, as negociações ocorreram em um nível industrial intermediário, meso; os atores-chave das negociações estavam setorialmente organizados, assim como as agências estatais envolvidas eram responsáveis pelas políticas setoriais da industria automobilística.

É fundamental registrar, porém, que as entidades tanto do Capital quanto do Traballho exibiram uma representatividade e legitimidade muito superior às estabelecidas pela força da lei. O que nos levou a reconhecer que 0 peso das relações corporatistas para a conformação da câmara automotiva seria bem menor do que o sugerido pelas amarras da tradição.

\section{A emergência do corporatismo tripartite}

Atkinson e Coleman observaram precisamente que "enquanto as políticas de gestão macroeconômica são usadas para delinear o amplo curso do desenvolvimento econômico, as políticas industriais são, por natureza, setoriais", na medida mesmo em que "requerem o desdobramento estratégico de instrumentos especiais para atingir as metas que são específicas para cada setor industrial" (Atkinson \& Coleman, 1985, p. 22).

A câmara automotiva brasileira, como instrumento de formulação e implementação de uma política industrial, enfatizou dois aspectos na sua constituição e na definição de seus objetivos:

1) o de um ajuste setorial, que visava recuperar o setor, reforçar vantagens comparativas e implantar métodos mais eficientes de produção, a partir de um melhor entrosamento entre Estado, Capital e Trabalho;

${ }^{16} \mathrm{O}$ fato de que muitas metas foram modificadas, cumpridas de modo parcial ou simplesmente deixadas de lado, não interferem, neste momento, em nossa discussão.
2) o de uma ampla reestruturação do setor, que buscava a renovação diante das profundas alterações na economia nacional e internacional.
O diagnóstico que esteve na origem da constituição da câmara automotiva e que sustentou o primeiro acordo em março de 1992 definiu consensualmente metas de curto, médio e de longo prazo $^{16}$. O perfil meso da articulação estava dado pelo recorte efetivado na estrutura produtiva, que permitia reunir as organizações representativas de todos os segmentos vinculados ao setor automobilístico. 
O surgimento desse arranjo no setor automotivo deveu-se basicamente a três fatores:

1) a existência de um consenso mínimo em torno da necessidade de se procurar soluções em parceria, diante da situação de crise profunda do setor;

2) a existência de entidades de trabalhadores e de empresários com representatividade fora e dentro de suas categorias, capazes de tomar decisões centralizadamente, sem que sua legitimidade fosse questionada;

3) o consentimento do Estado, naquele momento, em dividir prerrogativas, e de impulsionar a elaboração de uma política setorial.

O primeiro fator remete-nos à disposição de negociar; o segundo, à capacidade dos atores de construir uma estrutura mesocorporatista para isso; o terceiro, à possibilidade de instauração de um espaço tripartite e democrático de negociação, com características quase-públicas, concedidas pelo Estado.

A introdução na análise dos elementos acima indicados pareceunos fundamental para evitar que a discussão da forma do arranjo, no caso brasileiro, venha a ser inadvertidamente desvinculada da ação política das lideranças e do ambiente democrático em que este se desenvolveu.

No caso brasileiro, essa relação é clara: com a participação, os trabalhadores alcançaram benefícios que não atingiriam fora da câmara. Ao mesmo tempo, a participação dos sindicatos, além de favorecer a criação de um ambiente mais propício à reestruturação produtiva, deu-se através de propostas para a definição de uma política industrial qualitativamente melhores e mais adequadas do que as sugeridas pelas entidades empresariais e agências do Estado.

\section{O governo de interesses privados}

Até agora procuramos discutir as modalidades de relacionamento entre o Estado e os grupos de interesse e destes entre si. Os trabalhos de Streeck e Schmitter sobre o "governo de interesses privados" (1985) avaliaram até que ponto os interesses públicos podem ser atendidos por organizações privadas, que agem em conjunto com as agências estatais, mas que não são controladas por estas.

O importante a destacar é o processo em que o Estado delega, ainda que parcialmente, sua autoridade às organizações de interesse, que aceitam "livremente" esse poder. As aspas foram utilizadas porque o gesto é mais complexo: 1) se as organizações não aceitarem a oferta do Estado, este definirá autonomamente as orientações da política econômica; 2) se aceitarem, estarão construindo uma barreira de auto-proteção e contribuindo para a constituição de um mercado regulado, do qual poderão beneficiar-se mais do que em um mercado aberto; 3) mas, ao mesmo tempo, terão de fazer concessões por isso.

A câmara automotiva, em sua constituição, percorreu a trajetória acima. Porém, em primeiro lugar, interrogamo-nos pelos motivos que teriam 
levado o Estado a buscar esse tipo de solução de compromisso.

E a resposta que encontramos remeteu-nos exatamente para a avaliação da capacidade de intervenção estatal e das organizações interessadas.

Inspirando-nos em Streeck e Schmitter, observamos que no momento em que se formou a câmara automotiva:

1) O setor ocupava um lugar estratégico no dispositivo industrial brasileiro e as agências estatais não tinham conhecimento, experiência nem informações para elaborar e implementar uma regulamentação eficiente;

2) Apesar de ter promovido a abertura da economia, a brutal queda no desempenho do setor automobilístico, com forte impacto social provocava sérias dúvidas sobre a capacidade de sua recuperação sem nenhuma interferência nos mecanismos de mercado;

3) Mesmo que tivesse os recursos acima, o Estado teria enormes dificuldades para implementar sua política unilateralmente, uma vez que o peso político-econômico-organizativo das entidades do setor era muito grande;

4) OEstado ganhava legitimidade em uma sociedade ainda marcada pela ultracentralização dos regimes militares ao ceder parte de seu poder de decisão sobre a política industrial;

5) Ao estimular a câmara setorial, o Estado tentava diminuir os conflitos nas regiões particularmente sensíveis da economia e da política, sem exercer diretamente sua autoridade, uma vez que as associações integrantes do acordo passariam a assumir essa responsabilidade.

Evidentemente, essa intermediação não oferecia somente vantagens. Havia perigos flagrantes que continuam a fomentar acesas polêmicas sobre a experiência das câmaras setoriais até os dias de hoje. Destes, os mais significativos eram: 1) a possibilidade de colonização do Estado pelos grupos de interesse; 2) a submissão desses grupos às diretivas do Estado; 3) uma cooptação dos sindicatos de trabalhadores pelas grandes empresas, visando a drenagem de recursos ou benefícios públicos para o setor privado.

Somente a prática da elaboração coletiva, com o reconhecimento do perfil de cada um dos participantes, poderia evitar ou, pelo menos, diminuir os riscos colocados.

Isso porque, o principal ator nos arranjos neocorporatistas continua sendo o Estado e a experiência brasileira ilustra bem essa afirmação. Seu poder seria exercido de forma mais flagrante principalmente na construção do segundo acordo, uma vez que no primeiro, os representantes do Capital e do Trabalho também desempenharam papel político de primeira importância, em especial na definição da agenda de discussões e da programação dos grupos de trabalho.

Mesmo em crise, foi a partir do estímulo estatal que as câmaras começaram a se constituir, encontrando, inclusive, resistências iniciais tanto entre os representantes dos trabalhadores como dos empresários.

Afirmar o Estado como o principal componente dos processos corporatistas, não significa atribuir-lhe características orwellianas. Longe disso.

O papel desempenhado no mundo da economia e da política pela 
câmara automotiva evidenciou que importantes instituições do Estado - como a burocracia, empresas públicas e as diversas agências de planejamento, implementação e controle de políticas - estavam dividindo prerrogativas e, por essa via, assumindo orientações que não emanavam, exclusivamente, das decisões governamentais.

O passo foi tímido, as resistências foram muitas mas a curta experiência da câmara automotiva, corroborada pelo funcionamento de outras câmaras, já mostrou que é possível uma nova forma de se fazer política sem a retomada do velho corporativismo, por mais que este insista em sobreviver.

\section{A construção dos setores}

Nos anos 80 e 90, novas vertentes de reflexão sobre o Estado no capitalismo moderno seriam abertas pelo pensamento corporatista.

Segundo Schmitter (1990), as sociedades capitalistas estariam alterando suas estruturas de funcionamento: os níveis "setoriais" e "transnacionais" estariam ganhando espaço como locus privilegiado de organização de novas estruturas institucionais, em detrimento do nível "nacional".

Para o autor, apesar da razão capitalista permanecer a mesma - a busca da maximização dos lucros, a competição, a tendência à expansão e à acumulação - a forma de organização e realização do capital estaria se alterando.

Sem se dar conta desse movimento, diversos pesquisadores generalizaram experiências do entre-guerras e descobriram uma nova tendência mundial: a do "capitalismo organizado". A expressão, cunhada durante a República de Weimar, referia-se às novas realidades do capitalismo e, simultaneamente, às respostas que a social-democracia alemã dava para elas.

As características principais desse novo e organizado capitalismo eram: 1) a disseminação das associações de interesse pela sociedade, alterando o papel dos indivíduos em sua participação no mercado; 2) a incorporação dessas associações no processo político, diminuindo a influência tradicional dos partidos e dos parlamentos, e reduzindo a ocorrência de movimentações grevistas e lockouts; 3) a inclusão dessas associações em negociações e acordos tripartites, ampliando as metas da política macroeconômica e social, substituindo mecanismos de mercado e a velha intervenção estatal por novas práticas de formação de consenso e de auto-regulação coletiva.

Esse "capitalismo organizado" fincou raízes em pequenos países europeus, que construíram novas formas de contrato social entre grupos de interesse da sociedade. Diante da crise do mercado internaciomal, do desemprego, da queda dos salários, os sindicatos de trabalhadores e os empresários convergiram para um compromisso entre classes que, efetivamente, por um certo período, conseguiu estabilizar essas economias.

O “Tratado de Paz Social”, na Suíça de 1937, e o "Grande Acordo 
Sueco", de 1938, foram os precursores do corporatismo moderno, ainda que esse termo tenha sido cuidadosamente evitado devido à sua apropriação por Mussolini, Salazar e outros.

Após a $2^{\mathrm{a}}$ Guerra Mundial, a Holanda e a Bélgica, primeiro, a Noruega e a Dinamarca depois, seguiram no mesmo rumo. A Finlândia avançaria mais lentamente na mesma direção. E a Áustria tornar-se-ia o exemplo de organização corporatista do capitalismo democrático.

De um modo geral, podemos afirmar que esse "capitalismo organizado" desenvolveu-se em pequenos países com ampla organização de classe, com fortes partidos social-democratas e com economias altamente internacionalizadas. Do ponto de vista político e social, esses países contavam com: 1) ampla liberdade de organização; 2) grande capacidade de ação coletiva, o que possibilitou melhorias em seu nível de vida; 3) compromissos públicos pelo pleno emprego; 4) legitimidade para alterar os rumos da economia, ampliando a especialização profissional, o planejamento, a flexibilização do trabalho e o controle dos salários, de modo que a busca de competitividade internacional pôde basear-se em forte compromisso de paz social.

Esses elementos apareceram para muitos estudiosos do corporatismo através da visualização de uma tendência inelutável que empurraria as sociedades industriais avançadas em direção às negociações, acordos e pactos entre as classes.

Anos depois, o advento da era Reagan, a determinação do neoliberalismo de Thatcher e a derrota da social-democracia na Suécia e na Noruega acalmaram os ânimos daqueles que haviam detectado uma tendência inexorável em direção à modernização das sociedades regidas por macropactos.

As previsões de um "capitalismo organizado" confrontavam-se agora com um sistema que aparecia desorganizado, que revitalizava a competição, desregulamentava os mercados nacionais e globalizava a economia, dispersando os capitais por todo o planeta. Os acordos nacionais entravam em zona de turbulência. Os compromissos com o Welfare State e o pleno emprego, ao invés de crescerem, retraíam-se, enquanto os sindicatos sangravam em suas forças e enfraqueciam-se na sustentação dos pactos tripartite.

O Estado regulador, que parecera um imperativo para uma avançada reprodução capitalista, agora era visto e apresentado como um obstáculo ao desenvolvimento.

Como analisar essas alterações? O capitalismo estaria mesmo se desorganizando? O neoliberalismo triunfando? E o neocorporatismo sendo descartado?

Estudos comparativos entre os três mega-mercados - o americano, o europeu e o japonês - alertaram sobre a diversidade de dispositivos competitivos, de maximização de lucros, de expansão e realização capitalista, que convidavam os pesquisadores a um olhar mais acurado. 
Segundo Schmitter (1990) ${ }^{17}$, não estávamos assistindo a uma desorganização do capitalismo mas à uma reorganização estrutural que tem embaçado nossos olhos. Tratava-se, antes de mais nada, de acertar o foco da nossa visão.

Isso porque:

1) Apesar da aparente homogeneização do sistema capitalista mundial, suas práticas estão cada vez mais diversificadas no interior das economias nacionais e, ao mesmo tempo, mais sintonizadas através das economias nacionais;

2) As novas tecnologias, as novas estruturas de mercado e até mesmo as políticas públicas estão se reorientando para níveis intermediários entre a macro e a microeconomia, entre as políticas de grande porte e as das empresas;

3) Durante um certo período, a abordagem setorial indicou apenas uma escolha metodológica. Atualmente, porém, os setores e as regiões estão dando origem a ambientes novos, em que o intercâmbio entre produtores podem ser socialmente construídos;

4) Esses setores não estão dados de antemão, mas podem ser criados de modo que as políticas públicas possam interagir com suas elaborações e inovações.

O capitalismo procura os mais diferentes meios para produzir e realizar suas trocas, sendo que o setor é um desses espaços. No entanto, o estudo do capitalismo através dos setores não é uma tarefa simples, uma vez que os setores não constituem um simples dado da realidade.

"Sectors are artifacts", diz Schmitter (1990, p. 14).

A definição de seus integrantes e a delimitação de suas fronteiras comportam uma dose de escolha política e econômica. Isso significa que os setores parecem existir objetivamente nos mapas estatísticos, geográficos, econômicos e mesmo nos códigos legais. Mas, de fato, eles são criados por agentes sociais, exatamente para tentar reduzir as incertezas, aumentar a competitividade e diminuir custos - inclusive sociais - nas suas transações.

Nesse sentido, o Estado apresenta-se como uma espécie de patrocinador: por ser o único agente capaz de controlar uma série de fatores econômicos - impostos, taxas, alíquotas, financiamentos, incentivos - pode transferir parte de seu poder para os arranjos setoriais.

A tradição do pensamento brasileiro também não fugiu à tentação do olhar macro.

Freqüentemente foram deixados de lado os níveis intermediários, onde encontram-se em atividade um enorme número de mecanismos - grupos, aglomerados, coalizões, associações, etc. - nem sempre formalizados, que regulam as transações e o intercâmbio intra e intersetorial.

A partir dessa reflexão, podemos ampliar a configuração do mesocorporatismo, enriquecendo suas primeiras formulações que o aproximavam de um recorte "longitudinal" e "objetivo" da sociedade e da economia. Os estudos de Schmitter ajudaram-nos a perceber o jogo dos ingredientes

${ }^{17}$ Especialmente o capítulo Sectors and a new model for the comparative study of capitalism. 
políticos que alimentam a construção de setores no capitalismo contemporâneo.

\section{Pluralismo e corporatismo}

As mutações do capitalismo estariam estimulando a busca de uma nova teoria política, capaz de evitar a generalidade do olhar macro e a especificidade do micro. Foi com essa pretensão que Cawson procurou apreender a diversidade dos organismos que coexistem na sociedade capitalista, cuja racionalidade seria revelada por um instrumental capaz de combinar aspectos da teoria pluralista e marxista.

A abordagem então desenvolvida procurou explicar setorialmente o surgimento de mecanismos corporatistas que passaram a conviver ao lado de formações e processos tipicamente pluralistas em várias sociedades democráticas.

Esse movimento foi mais intenso onde o Estado patrocinou a elaboração e a implementação de políticas industriais. A interferência direta e seletiva do Estado através da aplicação de políticas industriais favoreceria a constituição de arranjos corporatistas. Em outras áreas da economia e da sociedade, diferentemente, os processos políticos livremente competitivos e mais tradicionais tenderiam a ser dominantes.

Essa questão é central. A distinção dos processos acompanha uma diferenciação existente entre as agências estatais voltadas para as esferas do consumo e aquelas responsáveis pela produção. Funções, atribuições, composição e interesses diversificados tenderiam a solicitar diversos tipos de organização.

Cawson estabeleceu uma correspondência entre essa diversificação e a atuação do Estado em seus vários níveis de organização.

De um modo geral, os governos locais estariam voltados, prioritariamente, para os serviços de atendimento ao bem-estar das comunidades e municípios. Os mecanismos macro seriam responsáveis pelas decisões sobre as políticas econômicas nacionais. E as políticas industriais, por sua vez, estariam mais diretamente ligadas aos níveis intermediários, ou meso.

Para que o Estado possa implementar uma política industrial em parceria com entidades da sociedade é preciso, além de um alto grau de organização dos interesses privados, que as agências governamentais responsáveis tenham legitimidade para decidir e encaminhar suas decisões. Isso porque, antes de mais nada, o sucesso de uma política industrial depende muito da forma e da velocidade com que os grupos produtores adaptam-se (ou não) aos ajustes da economia.

Os estudos de Cawson detiveram-se nas relações especiais estabelecidas entre o Estado e grupos de interesse que estimularam setorialmente a economia, através de processos de concertação voltados para a ampliação da qualidade e da competitividade industrial. Esses arranjos, 
denominados mesocorporatistas revelaram-se como mecanismos voca-cionados para a produção de políticas seletivas destinadas a um setor do mercado regulado pelo Estado.

Os pressupostos de Cawson sugerem, portanto, uma "abordagem dual" da sociedade, a partir do reconhecimento de que a economia não é estruturada apenas a partir das noções do mercado liberal, da competição ou da regulação. No horizonte, a tentativa de superação da disputa simplificadora do pluralismo versus corporatismo. A utilização do conceito de mesocorporatismo oferece-nos, assim, uma estrutura diferencial e mais rica de análise da política e da economia.

Ao mesmo tempo em que essas reflexões ajudaram-nos a discutir a natureza das câmaras setoriais, temos consciência de que os estudos neocorporatistas não construíram uma nova teoria política capaz de nos fornecer, em particular, uma visão geral do Estado na sociedade capitalista.

Ainda que essa ausência não tenha nos impedido de trabalhar, compartilhamos a preocupação de Williamson, para quem uma "teoria do Estado continua sendo, fundamentalmente, o elo perdido" (Williamson, 1989, p. 136) das análises corporatistas.

Diante dessa realidade, optamos por registrar alguns pontos que nos pareceram mais adequados e promissores no instrumental neocorporatista e que estimularam nossa reflexão sobre a atuação do Estado no capitalismo:

1) Nosso trabalho não está sugerindo que as câmaras setoriais sejam vistas como sinais do surgimento de uma nova tendência de organização da sociedade brasileira. Apenas procuramos chamar a atenção para as características particulares desses organismos, que, embalados pela democracia e pela crise do corporativismo tradicional, passaram a coexistir na sociedade ao lado de formas tipicamente pluralistas e corporatistas. Isso significa afirmar que as relações entre o Estado e os interesses organizados nem sempre são as mesmas;

2) A disposição do Estado de negociar a elaboração e a implementação de políticas industriais indica a ausência de condições para que a sua política seja imposta para um dado setor da economia. Sobre essa base, os arranjos mesocorporatistas intervêm exatamente quando um sistema de trocas e concessões se estabelece, visando a aplicação - e o êxito - de uma política industrial. São exatamente essas novas relações que explicam a natureza quase-pública desses organismos de formulação, implementação e de concertação de políticas. O poder político e econômico dos arranjos mesocorporatistas seria construído pela articulação dos grupos de interesse e, ao mesmo tempo, concedido pelo Estado;

3) As decisões dos organismos corporatistas resultam de processos de negociação, que, necessariamente, atribuem aos participantes poderes de sanção, de veto e de fiscalização - ainda que desiguais. Se atentarmos para a câmara automotiva, podemos ver que as entidades participantes não 
conseguiram operacionalizar as políticas independentemente do Estado, e este também não conseguiu controlar diretamente as forças e entidades que estão negociando ${ }^{18}$. Em outras palavras, o Estado opera, em geral, de modo a proteger a acumulação do capital. No entanto, por ser distinto de um "comitê executivo da burguesia", o Estado precisa legitimar a sua intervenção junto aos representantes tanto do capital quanto do trabalho;

4) A busca e a afirmação dessa legitimidade sugere que os arranjos mesocorporatistas não estão assentados diretamente sobre as relações estruturais entre as classes que se manifestam na sociedade. A concessão de poderes parciais aos arranjos significa uma diminuição correspondente de poderes do governo instituído, pelo menos no que diz respeito à política setorial elaborada em comum.

Como resultado, temos que uma parcela do corpo administrativo do Estado também passa a ser beneficiada por essa transferência de poder ${ }^{19}$. Paradoxalmente, um governo eleito, deixaria, portanto, de controlar totalmente um setor do aparelho de Estado. Essa observação baseia-se em uma distinção conceitual entre Estado e governo, e permite-nos apreender os conflitos e tensões que coexistem no interior da estrutura estatal;

5) Em nosso trabalho, a macroanálise do Estado cedeu lugar ao estudo de um sistema de relações de poder, capaz de combinar lógicas diferentes. Ao discutir a câmara automotiva como um arranjo mesocorporatista procuramos apreender apenas uma parte do sistema estatal, a que está vinculada à produção industrial;

6) O Estado, dessa forma, foi visto como um sistema diversificado de estruturas que desempenham diferentes funções, sistematicamente submetidas a comandos e pressões conflitantes. A questão que se colocou para nós, portanto, não foi a de buscar um suposto interesse geral do Estado, mas o de localizar o seu interesse na área específica da produção industrial que estudamos, o setor automotivo.

${ }^{18}$ As atitudes unilaterais assumidas sempre provocaram distúrbio na câmara e na implementação das orientações, como mostraram, por exemplo, as decisões sobre o Fus$c a$ e o rebaixamento das alíquotas de importação.

${ }^{19} \mathrm{O}$ que significa que outro setor do corpo estatal pode perder poder. As resistências de um setor da burocracia à instalação da câmara do transporte aéreo é ilustrativa desse processo.

${ }^{20} \mathrm{Cf}$. David Cameron,

1591984); Gosta EspingAndersen \& Walter Korpi (1984); Fritz

\section{As fronteiras do mesocorporatismo}

Os processos de elaboração e implementação de políticas industriais realizam-se através de uma verdadeira rede de tensões que percorrem o Estado, manifestando-se entre as agências estatais e os grupos de interesse da sociedade, assim como entre estes e sua base, das lideranças aos filiados. Estudos desenvolvidos em países da Europa Ocidental mostram que os arranjos corporatistas têm mostrado sua eficácia exatamente na diminuição do grau dessas tensões entre os vários segmentos produtivos e as agências estatais.

As anotações que seguem procuram sistematizar as articulações do instrumental neocorporatista, em um nível meso, que utilizamos em nosso estudo:

1) Os principais participantes dos arranjos mesocorporatistas são os agentes produtores, as associações de produtores (de empregados e 
empregadores) e o Estado. A análise isolada de cada um desses componentes pode levar-nos a perder de vista o ponto essencial do neocorporatismo, a saber, as relações entre os grupos de interesse e o Estado. Em nosso trabalho, o corporatismo será entendido tanto como "organização" (Schmitter), quanto como "elaboração e implementação de políticas" (Lehmbruch). Ou, como afirma Cawson, como fusão dessas duas características;

2) Apesar da retomada dos conceitos neocorporatistas nos anos 70 , a maior parte dos estudos até o início da década de 80 fixou-se, predominantemente, nos arranjos macro, entre o Estado e os grandes representantes do Capital e do Trabalho.

Nesse período, os principais trabalhos sobre os países da Europa Ocidental discutiram os pactos nacionais tripartite e suas repercussões na economia e na política. Os resultados positivos de vários acordos nacionais, que negociaram a elaboração e implantação de políticas públicas, incentivaram as pesquisas sobre esses processos em que as autoridades públicas apareceram dividindo responsabilidades com organizações privadas, como enfatizaram Schmitter e Lehmbruch;

3) A participação dos sindicatos de trabalhadores em mecanismos de cooperação com os empresários e o Estado, assim como a obtenção de nítidas vantagens materiais também estimularia outras abordagens ${ }^{20}$. Panitch (1979), de um outro ângulo, destacou que o corporatismo era um canal utilizado pelo Estado para impor a colaboração de classes aos sindicatos; e Crouch (1978), que o corporatismo era um meio de subordinar o movimento dos trabalhadores;

4) As grandes organizações do Trabalho e do Capital, no entanto, não se limitaram à elaboração de políticas distributivistas e de emprego.

Em vários países europeus os organismos tripartite passaram a planejar globalmente a economia, através da definição de políticas fiscais, da elaboração de orçamentos nacionais e da seleção de modalidades e gastos do Welfare State. Evidentemente, esse amplo envolvimento das organizações de empregados e empregadores realizou-se através de políticas compensatórias, dentre as quais se destacaram e o rebaixamento de expectativas salariais e dos preços ao consumidor. Esses acordos, no entanto, embora englobassem modalidades de intercâmbio político (cf. Regini, 1984), eram marcados pela parceria com o Estado na administração da economia;

5) Nos anos 80 uma nova alteração nas preocupações dos pesquisadores começaria a se manifestar. Os pactos nacionais, como objeto de análise, mostravam-se insuficientes para justificar uma abordagem mais ampla do capitalismo.

O olhar macro começou então a ceder lugar para os níveis meso e mesmo para o micro. Os arranjos encontrados eram menos visíveis porém, muitas vezes, mais duradouros e eficazes. A novidade foi que as abordagens meso e micro começaram a revelar a existência de uma verdadeira malha de relações entre o Estado e os grupos de interesse, que se realizavam através de 
uma multiplicidade de canais e cuja visibilidade vinha sendo ofuscada pelos macroenfoques.

6) O delineamento da noção de mesocorporatismo teve, pelo menos, duas consequências analíticas.

A primeira versou sobre os critérios para a avaliação do grau de desenvolvimento do corporatismo nos mais diferentes países: deixou-se de medir o grau de corporatismo apenas a partir do nível macro. Com isso, vários países tradicionalmente excluídos de qualquer discussão sobre o corporatismo, passaram a ser rediscutidos e reclassificados. O questionamento, no entanto, era de fundo e atingia, na verdade, as pré-condições até então reconhecidas como essenciais para o desenvolvimento desse tipo de mecanismo.

Vários autores procuraram explicar a tendência ao corporatismo na Europa como uma resposta à complexidade do capitalismo moderno, que solicitava uma participação política dos sindicatos (cf. Goldthorpe, 1984 e Korpi, 1983), facilitada quando partidos reformistas e vinculados aos trabalhadores alcançavam o governo. Para Goldthorpe, o corporatismo surgia em países:

"Nos quais os partidos social-democratas desempenharam um papel dominante no governo" e "os movimentos sindicais estavam melhor preparados para participar da negociação política e tinham maior confiança nos eventuais ganhos pois tinham fortes vínculos ideológicos e organizacionais com o partido governamental" (Goldthorpe, 1984, p. 328).

A tese, compartilhada por Maier (1984), vinculava a emergência de arranjos corporatistas à presença de fortes agremiações social-democratas que, de acordo com seu estilo reformista, incentivava a regulação consensual da economia e da política.

Por não contarem com partidos reformistas vinculados aos trabalhadores, nem com fortes associações nacionais, por marginalizarem sistematicamente os sindicatos da elaboração das políticas públicas e com a articulação parlamento-sociedade sendo feita via comissões de trabalho, através de um sistema de grupos de pressão organizados, os Estados Unidos eram um exemplo de país onde o corporatismo não poderia vingar. A Inglaterra, tradicionalmente liberal, e com associações nacionais relativamente frágeis, também ficava distante de qualquer classificação nesse sentido. E o Estado francês, fortemente centralizado e capacitado para o planejamento, inibia, nas análises, o surgimento de arranjos corporatistas.

A partir da definição dos contornos mesocorporatistas, estudos mais recentes começaram a identificar a existência de mecanismos de elaboração e de implementação de políticas, com claros contornos corporatistas, tanto no nível meso quanto no micro, na França (cf. Rhodes, 1985) na Inglaterra (cf. Bonnett, 1985) e também nos Estados Unidos (cf. Milward \& Francisco, 1983).

A segunda consequência incidiu sobre as formas possíveis do 
corporatismo. A visão nacional associou o corporatismo aos arranjos tripartite, entre o Estado, o Capital e o Trabalho. Os estudos sobre os níveis meso e micro encontraram formações corporatistas que não contavam com nenhuma representação dos trabalhadores. Isso indicava que nos níveis subnacionais, os mecanismos corporatistas poderiam assumir formas distintas do nível macro, o que ensejou uma rediscussão de uma série de características consolidadas exclusivamente a partir dos estudos macro.

7) No início dos anos 80 , Schmitter estruturou um quadro comparativo a partir do que considerava chave para a compreensão dos macroarranjos: as características estruturais dos sindicatos, das quais destacava o grau de centralização organizativa e do monopólio da representação (Schmitter, 1983, p. 429).

Lehmbruch também desenvolveu um trabalho comparativo, construído, porém, a partir do grau de participação dos grupos de interesse na formulação de políticas. Se compararmos os dois resultados teremos o seguinte:

Comparação entre países segundo o grau de corporatismo

\begin{tabular}{|c|c|c|c|c|}
\hline & Forte & Médio & Fraco & Pluralismo \\
\hline Schmitter & $\begin{array}{l}\text { Áustria } \\
\text { Dinamarca } \\
\text { Noruega } \\
\text { Finlândia } \\
\text { Suécia }\end{array}$ & $\begin{array}{l}\text { Holanda } \\
\text { Bélgica } \\
\text { Alemanha } \\
\text { Suíça }\end{array}$ & $\begin{array}{l}\text { Canadá } \\
\text { Irlanda } \\
\text { EUA } \\
\text { Inglaterra }\end{array}$ & \\
\hline Lehmbruch & $\begin{array}{l}\text { Áustria } \\
\text { Suécia } \\
\text { Noruega } \\
\text { Holanda }\end{array}$ & $\begin{array}{l}\text { Bélgica } \\
\text { Dinamarca } \\
\text { Alemanha } \\
\text { Finlândia } \\
\text { Suíça }\end{array}$ & $\begin{array}{l}\text { Inglaterra } \\
\text { Itália }\end{array}$ & $\begin{array}{l}\text { EUA } \\
\text { Canadá }\end{array}$ \\
\hline
\end{tabular}

Quadro 2

Fonte: Schmitter (1983) e Lehmbruch (1984).

Apesar das diferenças essenciais de critérios para a definição e mensuração dos índices de corporatismo, os resultados colhidos expressaram grandes semelhanças.

Na verdade, o olhar macro enfrentava dificuldades para captar as tensões no interior dos arranjos corporatistas, assim como as diversas modalidades de seu relacionamento com o Estado. Isso significa que o grau de corporatização registrado nas duas tabelas pode estar indicando apenas a intensidade de participação dos grupos de interesse na formulação de políticas.

Se essas considerações são procedentes, seria difícil, a partir do olhar macro, distinguir claramente um arranjo corporatista de um arranjo pluralista devidamente institucionalizado.

Mais do que a identificação das modalidades de arranjo, no entanto, as comparações internacionais ajudaram-nos a identificar as condições nacionais para a emergência do corporatismo.

A partir do quadro comparativo acima, poderíamos concluir que a ocorrência do macrocorporatismo seria maior nos pequenos países e menor 
nos grandes.

As dimensões territoriais, no entanto, não constituem indicadores seguros. Levando-se em conta a natureza dos mecanismos corporatistas talvez fosse mais adequado orientar as pesquisas para a determinação do grau de diferenciação/homogeneização social de cada país, o que poderia ensejar estruturas nacionais de representação de interesse mais ou menos uniformes. Ou para o acompanhamento da ação dos partidos social-democratas ou trabalhistas e à participação cooperativa dos sindicatos (cf. Schmitter, 1983). Ou então para a comparação de indicadores econômicos e políticos associados à ação corporatista.

Schmitter desenvolveu essa última vertente a partir do questionamento da tese pluralista que via no excesso de demanda dos grupos de interesse a razão das crises de governabilidade. Segundo este autor, não era a escala das demandas que poderia afetar a governabilidade, mas "a maneira como essas demandas eram processadas" (Schmitter, 1983, p. 432).

A partir de seu trabalho comparativo, Schmitter constatou que o macro-corporatismo era uma ferramenta útil às autoridades públicas na administração de fortes demandas sociais. Cameron (1984) chegou a uma conclusão semelhante, expondo a vinculação clara entre os arranjos macrocorporatistas e a persistência de baixas taxas de desemprego nos países europeus.

8) Desses estudos não se pode concluir que o corporatismo é necessariamente um mecanismo redutor do desemprego (ou indutor do emprego), redistribuidor de renda nem muito menos um automático nivelador de diferenças sociais. Infelizmente esses mecanismos não são dotados de poderes mágicos.

Acreditamos, porém, que a formulação e a implementação de políticas de compromisso entre o Estado, o Capital e o Trabalho, sem a estratégia do confronto, podem incrementar a atividade econômica, produzindo, assim, ganhos para todos os participantes, através de uma lógica distinta da soma-zero - ainda que esses ganhos não sejam iguais entre as partes.

Se os ganhos são para os participantes, podemos nos interrogar sobre as consequências do corporatismo para os interesses não organizados, ou debilmente organizados, que estão excluídos dos espaços que, por atribuição estatal, definem regras distintas do mercado.

Ou, em outras palavras, o que acontece com os setores que não têm acesso às arenas que decidem as políticas públicas?

É importante deixar claro que a constituição de arranjos corporatistas não modificam as bases estruturais da sociedade. Isso significa que os trabalhadores que sustentam a economia informal, os sem-registro, os desorganizados, enfim, todos aqueles que não possuem poder para influenciar o curso das decisões do Estado permanecem à margem desses benefícios: os mecanismos neocorporatistas, em sua configuração, continuam expressando as diferenças de poder na sociedade. 
O neocorporatismo está voltado basicamente para a organização da intervenção política e econômica nos setores produtivos. Isso significa que, de um modo geral, excluem da discussão - e dos benefícios, pelo menos em um primeiro momento - os setores mais frágeis da economia, uma vez que esses interesses serão representados apenas indiretamente, principalmente através do Estado.

9) Ao estudar as relações entre os grupos de interesse e o Estado podemos perceber como as características estruturais dos diferentes setores produtivos solicitam distintas formas de organização e de ação. Se analisarmos a produção industrial vemos que a natureza dos produtos, a presença de empresas estrangeiras, a prioridade de escoamento da produção no mercado interno, o privilégio de uma orientação exportadora, os níveis de competitividade, a maturidade do setor, a concentração de capitais e a sua taxa de crescimento induzem a diferentes formas de organização de interesses (cf. Atkinson \& Coleman, 1985).

Cawson indicou-nos nos que as "multinacionais (como na indústria automotiva) e as maiores empresas nacionais tendem a não reconhecer as associações de interesse e a negociar diretamente com as agências estatais através de arranjos micro-corporatistas bipartites" (Cawson, 1986, p. 111).

Essa foi, em linhas gerais, a história do setor automobilístico brasileiro, desde a sua constituição nos anos 50 .

No entanto, nas condições de deterioração do mercado e de declínio do setor, as grandes empresas procuram proteção contra a competição externa, solicitando a intervenção do Estado. Nos anos 90, quando foi constituída a câmara setorial, a indústria automobilística estava fortemente pressionada pela competição internacional, acossada pelos rebaixamento geral dos custos e sem perspectiva de uma estabilização setorial razoável, em função do ambiente de fortes conflitos trabalhistas.

A negociação mesocorporatista, então, constituiu-se em uma intervenção seletiva e coordenada no setor, permitindo sua reestruturação e racionalização. Essencialmente, o pressuposto dessa interferência no mercado, que resultou na coesão de grupos concorrenciais e de segmentos antagônicos, foi a existência de associações que monopolizavam a representação setorial. Uma frágil organização sindical, com toda certeza, teria preparado o terreno para a reedição de arranjos bipartite.

O centro da ação mesocorporatista foi a discussão de pontos capazes de impulsionar a estruturação de uma política industrial, a curto, médio e longo prazo. A câmara setorial, criada sob ameaça da competição internacional, consolidou medidas protecionistas, trouxe benefícios para os trabalhadores e, simultaneamente, estimulou a reestruturação produtiva do setor.

Essa política foi implementada pelos representantes do capital e do trabalho, em conjunto com as agências estatais, expressando uma fusão entre representação de interesses e a sua implementação, traço que distingue os arranjos corporatistas do jogo de pressões pluralista. 
10) A constituição da câmara automotiva só ocorreu porque houve um processo de constituição política de um setor industrial, através de um mecanismo mesocorporatista denominado câmara setorial.

No entanto, mesmo quando o mesocorporatismo é tripartite, o campo de oportunidades e constrangimentos configura-se distinto dos arranjos macro, pois os conflitos de classe estão circunscritos a um setor.

Na busca de proteção para um setor específico da indústria, as forças do Capital e do Trabalho compartilham mais interesses comuns do que nos arranjos macro. Isso significa que, teoricamente, o Vicentinho, presidente do Sindicato dos Metalúrgicos de São Bernardo, encontraria mais pontos de acordo com os empresários do setor automotivo e com as grandes montadoras do que o Vicente Paulo da Silva, presidente da CUT.

Nesse sentido, podemos dizer que nos arranjos mesocorporatistas, predominam os interesses específicos dos setores representados, diferentemente do macro-corporatismo, que realça exatamente os contrastes entre as classes, mesmo quando o objetivo é a celebração de acordos cooperativos.

Contrariamente às ilações ideológicas, a emergência do mesocorporatismo tripartite no setor automobilístico brasileiro não se deveu a alterações morais dos sindicalistas envolvidos. Mas foi o resultado da escolha de uma parcela dos trabalhadores metalúrgicos que utilizou o seu poder político e econômico, consolidado em mais de uma década de movimento sindical autêntico, na negociação de benefícios para um setor ameaçado diretamente em sua sobrevivência.

A câmara setorial automotiva mostrou-se eficaz na coordenação do processo de transição e na superação de uma crise setorial. Sem se constituir em panacéia, aproximou grupos rivais a partir do reconhecimento dos benefícios de médio e longo prazo que a ação coletiva poderia proporcionar em comparação com o mercado desregulado.

Apesar dessas características terem se enfraquecido durante $o$ ano de 1994, quando a câmara perdeu seu dinamismo após os anestésicos ministrados pelos órgãos de comando do Estado, ainda mantêm atualidade os comentários de Grant, para quem uma das principais atrações do neocorporatismo "é abrir a possibilidade de transformação do processo de gestão econômica em um jogo de soma não-zero, de modo que cada um possa ganhar mais do que na ausência de arranjos corporatistas - embora alguns ganhem mais do que os outros" (Grant, 1985, p. 25). 
ARBIX, Glauco.The corporatist dinasty. Tempo Social; Rev. Sociol. USP, S. Paulo, 8(1): 127159, May 1996.

ABSTRACT: This essay examines the most recent forms of the corporatist theory, especially its democratic patterns - called neo-corporatists. Positive experiences in the social, economic and political fields, particularly those developped in European countries, have drawn corporatism away from the strong stigma generated by fascist practice, regaining importance as a social sciences theme. In Brazil, the birth of the automobile sectoral chamber at the beginning of the nineties revealed the emergence of neo-corporatist mechanisms in the industry, sectorially limited in an intermediate level. This experience, politically and economically effective, is analysed as a mesocorporatist institucional arrangement.

\section{REFERÊNCIASBIBLOGRÁFCAS}

Arbix, Glauco. (1996) Uma aposta no futuro - a experiência da câmara setorial da indústria automobilística. São Paulo, Escritta (no prelo).

Atrinson, Michael \& Coleman, William. (1985) Corporatism and industrial policy, In: CAwson, Alan (ed.). Organized interests and the State - Studies in neo-corporatism. London, Sage.

BAREL, Yves. (1988) Un nouveau corporatisme? In: Colas, Dominique (ed.). L'État et les corporatismes. Paris, PUF.

Boito, Armando. (1991) O sindicalismo de estado no Brasil. São Paulo, UNICAMP/Hucitec.

BonNETt, Kevin (1985) Corporatism and thatcherism: is there life after death? In: CAwson, Alan (ed.). Organized interests and the State - Studies in neo-corporatism. London, Sage.

CAMERon, David. (1984) Social democracy, corporatism, labour quiescence, and the representation of economic interest in advanced capitalist society. In: Goldthorpe, John (ed.). Order and conflict in contemporary capitalism. Oxford, Clarendon Press.

Cawson, Alan. (1978) Pluralism, corporatism and the role of the State. Government and Opposition, $\mathrm{n}^{\circ} 13$. Apud Willianson. (1989) Corporatism in perspective. London, Sage. p. 15.

(ed.). (1985a) Organized interests and the State - Studies in neocorporatism. London, Sage.

. (1985b) Varieties of corporatism: the importance of the meso-level of interest intermediation. In: (ed.). Organized interests and the State - Studies in neo-corporatism. London, Sage.

. (1986) Corporatism and political theory. London, Basil Blackwell.
UNITERIMS: neo-corporatism, meso-corporatism, sectoral chamber, concertation, public policy, interests association. 
Crouch, Colin. (1978) The changing role of the State in industrial relations in western Europe. In: Crouch, C. \& Pizzorno, A. (eds.). The resurgence of class conflict in western Europe since 1968. Vol.II. London, MacMillan Press.

DurKheIM, E. (1978) La division du travail social. Paris, PUF.

Encyclique quadragesimo anno. (1937) Paris, Spes.

Encyclique rerum novarum. (1932) Paris, Spes.

EsPING-ANDERSEN, Gosta \& KorPI, Walter. (1984) Social policy as class politics in post-war capitalism: Scandinavia, Austria, and Germany. In: GOLDTHORPE, John (ed.). Order and conflit in comtemporany capitalism. New York, Oxford University Press.

Goldthorpe, John (ed.). (1984) Order and conflit in comtemporany capitalism. New York, Oxford University Press.

GrANT, Wyn. (1985) Introduction. In: The political economy of corporatism. Londres, MacMillan.

HobBes, Thomas. (1952) Leviathan. Chapter XXIX. Chicago, William Benton Publisher.

Jobert, Bruno \& Muller, Pierre. (1987) L'État en action. Paris, PUF.

Katzenstein, Peter J. (1985) Small States in world markets. Ithaca, Cornell University Press.

KoRPI, Walter. (1983) The democratic class struggle. London, Routledge.

Latin dictionary. (1987) LEWIS \& SHORT. New York, Oxford University Press.

LeHMBRUCH, Gerhard. (1979) Consociational democracy, class conflict and the new corporatism. In: Schmitter, P. \& Lehmbruch, G. (eds.). Trends toward corporatist intermediation. London, Sage.

. (1984) Concertation and the structure of corporatist networks. In: GoldTHORPE, John (ed.). Order and conflict in contemporary capitalism. New York, Oxford University Press.

MAIER, Charles S. (1984) Preconditions for corporatism, In: GoldTHORPE, John (ed.). Order and conflict in contemporary capitalism. New York, Oxford University Press.

Manoilesco, Mihail. (1938) O século do corporativismo. Rio de Janeiro, Livraria José Olympio/Editora.

Milward, H. \& Francisco, R. (1983) Subsystem politics and corporatism in the United States. Policy and Politics, $\mathrm{n}^{\circ} 11$.

Novo dicionário Aurélio da língua portuguesa. Rio de Janeiro, Editora Nova Fronteira.

O grande dicionário etimológico-prosódico da língua portuguêsa. (1964) BuENo, Francisco da Silva. São Paulo, Edições Saraiva. 
PANITCH, Leo. (1979) The Development of corporatism in liberal democracies. In: Schmitter, P. \& Lehmbruch, G. (eds.). Trends toward. corporatist intermediation. London, Sage.

REGINI, Marino. (1984) The conditions for political exchange: how concertation emerged and collapsed in Italy and Great Britain. In: GOLDTHORPE, John (ed.). Order and conflict in contemporary capitalism. New York, Oxford University Press.

RHODEs, Martin. (1985) Organized interests and industrial crisis management: reestructuring the steel industry in West Germany, Italy and France. In: Cawson, Alan (ed.). Organized Interests and the State - Studies in neo-corporatism. London, Sage.

Rodrigues, Leôncio Martins. (1990) Partidos e sindicatos. São Paulo, Ática. . (1991) O declínio do sindicalismo corporativo. Rio de Janeiro, Ibase.

Rosanvallon, Pierre, (1984) La crise de l'État-providence. Paris, Éditions du Seuil.

SchARPF, Fritz. (1984) Economic and institutional constraints of fullemployment strategies: Sweden, Austria, and West Germany, 19731982. In: Goldthorpe, John (ed.). Order and conflict in contemporary capitalism. New York, Oxford University Press.

Schmitter, Philippe C. (1974) Still the century of corporatism? In: Pike, F. \& STRITCH, T. (eds.). The new corporatism. London, University of Notre Dame Press.

. (1983) Intermediazione degli interesse e governabilità nei regimi contemporanei dell'Europa occidentale e dell' America del Nord. In: Berger, Suzanne (ed.). L'Organizzazione degli interessi nell'Europa occidentale. Bolonha, Il Mulino.

(1990) Sectors in modern capitalism: models of governance and variations in performance, In: BRUNETTA, Renato \& DELL'ARINGA, Carlo (eds.). Labour relations and economic performance. London, MacMillan.

StARobinski, Jean. (1970) Leo Spitzer et la lecture stylistique. In: SPITZER, Leo. Études de style. Paris, Gallimard, p. 12. Apud CoLI, Jorge. (1989) Prefácio. In: StARoBinski. 1789: os emblemas da razão. São Paulo, Companhia das Letras.

Streeck, Wolfgang \& Schmitter, P. (1985) Private interest government, beyond market and State. London, Sage.

The Oxford dictionary of current english. (1990) Oxford, Clarendon Press.

Williamson, Peter J. (1985) Varieties of corporatism - a conceptual discussion. Parte III. London, Cambridge University Press. . (1989) Corporatism in perspective. London, Sage, 1989. 
